Volume 2, Number 1, 2016

\title{
Peculiarities of Non-Stationary Pressure Measurement in Real Time
}

\author{
Myroslav Tykhan $^{*}$ \\ Lviv Polytechnic National University, 12, S. Bandery St., Lviv, 79013, Ukraine
}

Received: April 18, 2016. Revised: December 12,2016. Accepted: December 23, 2016

(C) 2016 The Authors. Published by Lviv Polytechnic National University.

\begin{abstract}
Nowadays, industrial development creates new and more complex processes leading to emergence of specific conditions for use of sensors and therefore specific measurement tasks. These circumstances lead to new requirements both for the methods of measurement and for sensors that implement these methods. Developments in microelectronic technologies and materials science have led to a significant number of types of pressure sensors. However, in recent years, despite the growing number of sensors range, it is in high-tech industries that the need for pressure sensors with fundamentally new features and characteristics has increased dramatically. This is caused by the need to rapidly measure unsteady pressure in real time, with a normalized error mostly within the static one. Taking this into account, the features of non-stationary pressure measurement in real time are analyzed in this paper and the necessary and sufficient requirements for sensors that allow their effective use are outlined. Thus, the goal of this work is the analysis of the process of measuring the non-stationary pressure in real time, aimed at identifying the peculiarities of the measurement problem and development of ways of its solution.
\end{abstract}

Keywords: peculiarities; measurement; unsteady; pressure; real time; sensor.

\section{Main features of the measurement task and peculiarities of the primary measuring transducer}

In today's high-tech systems (automotive, test benches for testing complex aerospace products, liquid rocket engines control systems, research, etc.) [1-6], in the measurement of pressure we only know its upper and lower limits while the nature of the measured value in time is mostly unstructured and unpredictable. That is, within one measurement pressure can be impulsive (shock pressure), and without sudden changes (smooth) - with constant or variable frequency, moreover, static areas can exist. At the same time these time features can alternate freely and at significantly different amplitudes.

In general, by the nature of non-stationary process, measured pressure can be divided into the following groups:

- considerably non-stationary pressure as a combination of shock and poly-harmonic pressure with the quasistatic pressure areas (it is the hardest dynamic mode);

- non-stationary pressure of shock nature;

- non-stationary pressure of harmonic or poly-harmonic nature.

The practice of designing piezoresistive pressure sensors is such that the sensor is a transducer chain, the first of which are mechanical transducers, elastic elements. Therefore, physics of primary measured transformation in dynamics is mechanical vibrations of elastic elements. So, speaking of eigenfrequency sensor, we mean the vibrations frequency of the chain of elastic mechanical transducers. For many types of sensors this is the frequency of natural oscillations of the membrane or membrane system secondary beam. Therefore, in case of piezoresistive sensors these are the features of elastic mechanical transducers vibration processes that determine non-stationary pressure measurement accuracy in general.

\footnotetext{
"Corresponding author. Email address: tykhanm@ukr.net
} 
It is known that given the non-stationary and rapidly changing process the measured values of fluctuations elastic element will contain transitional and well-established components. Thus, the sharper and the more transient the pressure is, the more pronounced and brighter the transient component is. In practice, when measuring the transient pressure we deal with transient processes [7]. However, unlike the overall dynamics of elastic systems, in terms of measurement, it is impossible to wait until transients processes cease to exist, or just ignore them because they are significant. A signal from the sensor at any given time is perceived by the control system as informative value, and any part of it entails a response. So, despite the fact that the measured pressure is unpredictable, we cannot "warn" the system when the transient and steady components end.

Since the initial measuring conversion is a mechanical vibration with strong transient and steady phases, the output signal of the sensor contains a dynamic error, which also has a dual nature.

We know that the transition phase error is most evident when measuring the rectangular pressure pulse $[7,8]$, and its maximum relative value is estimated by $\delta_{n}=e^{-\beta \cdot \frac{\pi}{\omega}}$ where $\beta$ is damping coefficient and $\omega$ is natural frequency of vibration of the sensor system.

Based on this relationship, it is obvious that in the transient dynamic mode, the maximum relative error is greater if the natural frequency of the sensor is higher, and smaller, if the fluctuations damping coefficient is greater. Therefore, in the elastic elements operation, the ratio of vibrations damping coefficient and natural frequency of the element is crucial.

For elastic elements, increase in its own oscillation frequency to some extent entails increase in the damping factor. In practice, for elastic elements of piezoresistive pressure sensors we get $\frac{\beta}{\omega}=0.3 \ldots 0.6$ [9]. Thus, the dynamic maximum error in the transient mode can be $\delta_{n}=e^{-\pi(0.3 \ldots 0.6)}=0.15 \ldots 0.39$, i.e. $15 \ldots 40 \%$. However, even with the additional measures to increase vibrations damping factor only, error still can be reduced slightly, but not significantly. However, increase in the oscillations damping factor will increase the phase shift which will result in the increase in measurement error. Obviously, this error is too big and makes it impossible to carry out measurement in modern critical systems.

In case of established form of vibrations, indeed based, on AFC (amplitude-frequency characteristics) of the sensor, the higher its frequency of oscillations, the wider range of measured pressure it can perceive with a particular error. However, increase in the natural frequency of oscillation increases the rigidity of the elastic system, which results in the direct loss of sensation and thus, significant limit in the ability to use the sensor.

Thus, the described features of the pressure measuring dynamics and initial conversion physics determine strategy for designing piezoresistive unsteady pressure sensors.

Today, to ensure efficiency and metrological reliability of control and automation systems, it is necessary to ensure the accuracy of the sensors themselves, especially in dynamic mode.

In non-stationary values measurement, such problem can be solved in two ways: by adjusting output value depending on the dynamic error determined in some way, or by restoring the input signal [10-15]. Efficiency of determining dynamic error depends primarily on the amount of a priori information about the nature of the measured pressure. However it is in many modern systems that require high-precision measurement of unsteady pressure that the volume of this information is minimal. Marginal peak pressure value only is mostly known. Therefore, the method of direct adjustment of the output signal in transient automation systems has no wide application.

On the other hand, the dynamic errors can be minimized in the structural way (variation of natural frequency, damping factor, etc.). However, because of inherent unrecoverable or immanent dynamic error, we qualitatively need different ways based on the theory of input recovery.

\section{Measurement of unsteady pressure as an incorrect task}

As it is known, the method for restoring the input signal belongs to a class of inverse problems. For the successful solution of this problem, it must be set correctly (according to J. Hadamard) and the correctness conditions are as follows [15]. 
1. There should be a solution to basic integral equation which describes the work of a linear system dynamics.

2. There should be one solution to the basic integral equation.

3. Solution to this equation should be stable, i.e. small perturbations (errors of measurement, outside influence) of the output signal should remain as small as in the restored input signal.

Since from the physical perspective, measurement transformation, which the sensor performs, is an oscillation of elastic elements, the work of pressure sensors, in general, is described by the Volterra integral equation or convolution integral

$$
u(t)=\int_{0}^{t} h(t-\tau) p(\tau) d \tau
$$

where $u(t)$ is output signal of the sensor; $h(t-\tau)$ is impulse transient function of the sensor; $p(\tau)$ is pressure being measured (input).

Equation (1) is an integral equation with symmetric kernel in class $L_{2}[0, t]$.

For the physical measurements, the first accuracy condition is met priori, as presently known types of piezoresistive pressure sensors belong to linear systems [16], and the solution to the integral equation (1) is an incoming signal itself which exists.

The second condition is not satisfied under any circumstances. This is explained as follows.

Let us substitute function in equation (1)

$$
p_{i}(\tau)=p(\tau)+\sum_{i=1}^{n} \alpha_{i} \cdot \psi_{i}(\tau)
$$

We get

$$
\begin{aligned}
& \int_{0}^{t} h(t-\tau)\left[p(\tau)+\sum_{i=1}^{n} \alpha_{i} \cdot \psi_{i}(\tau)\right] d \tau=\int_{0}^{t} h(t-\tau) p(\tau) d \tau+ \\
& +\int_{0}^{t} h(t-\tau) \sum_{i=1}^{n} \alpha_{i} \cdot \psi_{i}(\tau) d \tau=\int_{0}^{t} h(t-\tau) p(\tau) d \tau+\sum_{i=1}^{n} \alpha_{i} \cdot \int_{0}^{t} h(t-\tau) \psi_{i}(\tau) d \tau
\end{aligned}
$$

where $p(\tau)$ is the solution of equation $(1) ; \alpha_{i}$ are arbitrary constant values; $\psi_{1}(\tau) \ldots \psi_{n}(\tau)$ are some not equal to zero almost everywhere functions such that

$$
\int_{0}^{t} h(t-\tau) \psi_{i}(\tau) d \tau=0 ; i=1,2, \ldots, n
$$

In (3), the second summand because of assumption (4) is zero, so the whole expression (3) is $u(t)$. That is, $p_{i}(\tau)$ can also be interpreted as the measured input signal. This means that the input signal can be presented as many combinations of informative and third-party components, which will give the input signal observed in the measurement. Therefore, if the difference between measured value and input signal $p_{i}(\tau)-p(\tau)=\Delta(\tau)$ can be represented as a series $\sum_{i=1}^{n} \alpha_{i} \cdot \psi_{i}(\tau)$, then based on real output signal, the input signal (goal of measurement) is determined ambiguously.

On the other hand, [15] according to Borel's theorem on convolution, equation (1) using Fourier transform can be represented as follows

$$
H(\omega) \cdot P(\omega)=U(\omega)
$$


where, $U(\omega), H(\omega), P(\omega)$ are Fourier images of functions $u(t), h(t-\tau), p(\tau)$, i.e. range of output signal, transfer function of the sensor and input signal range respectively.

Therefore, using the inverse Fourier transform, solution to equation (1) is

$$
p(t)=\frac{1}{2 \pi} \int_{0}^{t} \frac{U(\omega)}{H(\omega)} \exp (j t \omega) d \omega
$$

However, the function $H(\omega)$ can be equal to zero in some points $\omega=\omega_{i}$, or turn out to be finite and outside some interval $\omega^{\prime} \leq \omega \leq \omega^{\prime \prime}$ be identical to zero $H(\omega) \equiv 0$.

Then the solution (1) can be obtained both from the function

$$
P(\omega)=U(\omega) / H(\omega) ; \omega \neq \omega_{i}
$$

and from the function

$$
P_{1}(\omega)=P(\omega)+\sum_{i} a_{i} \cdot \delta\left(\omega-\omega_{i}\right)
$$

and the input signal $p(t)$ will be

$$
p(t)=\frac{1}{2 \pi} \int_{0}^{t} \frac{U(\omega)}{H(\omega)} \exp (j t \omega) d \omega+\frac{1}{2 \pi} \sum_{i} a_{i} \cdot \exp \left(j t \omega_{i}\right)
$$

where $a_{i}$ are arbitrary constant values.

Thus, equation (1) does not have only one solution if the Fourier image of the sensor transfer function $H(\omega)$ is finite or in some points is equal to zero. Therefore, if the range of the input signal $P(\omega)$ has harmonics with frequencies that coincide with zero of the transfer function $H(\omega)$, these harmonics do not affect the output signal $u(t)$ and therefore cannot be uniquely recovered from it. Since the transfer functions of real pressure sensors are almost always equal to zero, and the length of the input signal spectrum because of its unsteadiness can be arbitrarily wide, from this point of view unsteady pressure measurement is a task set incorrectly.

In addition, the solution to the integral equation (1), the core of which belongs to a class $L_{2}[a, b]$ (set of functions integrated in a square on $[a, b]$ ), or $C[a, b]$ (a set of all continuous functions $[a, b]$ ) can be unstable [17, 18]. This fact is explained by the fact that the equation operator $\mathrm{Z}$ which operates in $L_{2}[a, b]$ or in $C[a, b]$ converts function $p(t)$ to function $u(t)$ according to the law

$$
Z[p(t)] \equiv \int_{0}^{t} h(t-\tau) p(\tau) d \tau=u(t)
$$

is a completely continuous operator. It reflects all the compact set of elements $\{p\}$ into a compact set of elements $\{\mathrm{Zp}\}$ since condition

$$
\int_{c}^{d} \int_{a}^{b}[h(x, \xi)]^{2} d x d \xi<+\infty
$$

for impulse functions of real sensors is met. However, the operator inverse to a fully continuous one is unlimited. Therefore, if $u_{1}(t)$ and $u_{2}(t)$ are two close elements of space $F$ and both equations $Z[p(t)]=u_{1}(t)$ and $\mathrm{Z}[p(t)]=u_{2}(t)$ have the solution, the corresponding solutions $\mathrm{Z}^{-1}\left[u_{1}(t)\right]=p(t)$ and $\mathrm{Z}^{-1}\left[u_{2}(t)\right]=p(t)$ may be 
considerably different. That is arbitrarily small error in determining the right side of equation (1) can lead to arbitrarily large error in the recovery of the input signal $p(t)$.

So, it is obvious that the last two correctness conditions of setting inverse problem of measurement are not met. So, unsteady pressure measurement is a clearly incorrect task that requires special methods to solve it.

\section{Conclusion}

Measurement of unsteady pressure, especially in real time, is a particularly complex technical and mathematical problem which cannot be solved using traditional methods. Obviously, this requires rethinking of the general theoretical concepts of non-stationary values measurement and the need for new research of the opportunities to address properly set task based on the characteristics of the measured value and peculiarities of instrumentation.

\section{References}

[1] Mokrov E. A. Scientific institute of the physical measurements: 45 years in space instrument making. Sensors and systems. - 2005. - No. 9. - p. 2-3 (in Russian).

[2] Markelov I. G. Complex of pressure sensors for exploitation on the objects of nuclear energy. Sensors \& Systems. - 2000. No. 11-12. p. 24-25 (in Russian).

[3] Sensors Web Portal: http://www.sensorsportal.com/html/sensors/Pressure.htm

[4] Sokolov L.V. An analysis of increasing requirements of micromechanics sensors and MEMS. Sensors and systems. - 2005. - No. 6. P. 41-43.(in Russian).

[5] Jackson R. G. The newest sensors / R. G. Jackson. - M.: Technospere, 2007. - 384 p.

[6] Tykhan M. The pressure sensor with self-diagnostics / M. Tykhan, e.t.c. // IX Scientific Conference on Optoelectronic and Electronic Sensors. Krakow-Zakopane, Poland. June 19-22. - 2006 - P. 85-88 (in Polish).

[7] Tykhan M. O. To the question of dynamics of pressure transducers / M. O.Tykhan // Automation of production processes and technical control in machine building and instrument making. Proc. of Lviv Polytechnic National University. - 2005. - No. 39. - P. 104-109 (in Ukrainian).

[8] Tykhan M. O. Optimization of parameters elastic elements of piezoresistive pressure sensor by means of dynamic characteristics / M.O.Tykhan // Measuring technique and metrology. Proc. of Lviv Polytechnic National University. - 2011. - No. 72. - p. 82-88 (in Ukrainian).

[9] Tykhan M. O. Evaluation of error of piezoresistive sensor of dynamic pressure / M. O. Tykhan // Optimization of production processes and technical control in machine building and instrument making. Proc. of Lviv Polytechnic National University. - 1995. - No. 290. - p. 91-96 (in Ukrainian).

[10] Solopchenko G. N. Compensation of dynamic errors with incomplete information about the properties of the instrument and the measurement signal / G. N. Solopchenko [and others] // Metrology. - M., 1979. - No. 8. - p. 3-13 (in Russian).

[11] Solopchenko G. N. Methods for taking into account the priori information in the correction of the measurement error in the measurement computation channel in the dynamic mode / G. N. Solopchenko [and others] // Research in the field of evaluation of measurement errors: Digest of scientific proceedings VNIIM. - M., 1986. - p. 27-31 (in Russian).

[12] Burovtseva T. I., Zvyagintsev A. M. Correction of sensor error by the methods of fuzzy logic / T. I. Burovtseva, A. M. Zvyagintsev // Sensors and systems. - 1999. - No. 7. - p. 14-21 (in Russian).

[13] Granovsky V. A. Estimation and correction of dynamic error of measuring instruments / V. A. Granovsky, Y. S. Etinger // Research in the field of evaluation of measurement errors: Digest of scientific proceedings VNIIM. - Leningrad, 1986. - p. $32-35$ (in Russian).

[14] Zemelman M. A. Automatic correction of errors of measuring devices / M. A. Zemelman. - M.: Publishing House of Standards, 1972. 199 p. (in Russian).

[15] Vasylenko G. I. Theory of restoration of signals: About reduction to the ideal device in physics and technique. - M.: Sov. radio, 1979. p. 272 (in Russian).

[16] Azizov A. M. Precision of measuring transducers / A. M. Azizov, A. N. Gordov. - - L.: Energy, 1975. - 256 p. (in Russian).

[17] Tikhonov A. N. Methods for solving the incorrect problems / A. N. Tikhonov, V. Y. Arsenin. $-2^{\text {nd }}$ Publishing. - M.: Nauka, $1979 .-284$ p. (in Russian).

[18] Tikhonov A. N. Regularizing algorithms and prior information / A. N. Tikhonov [and others] . - M.: Nauka, 1983. - 197 p. (in Russian). 


\title{
Специфіка вимірювання нестаціонарного тиску в реальному часі
}

\author{
Мирослав Тихан \\ Національний університет «Львівська політехніка», вул. С. Бандери, 12, Львів, 79013, Украӥна
}

\begin{abstract}
Анотація
Сьогодні розвиток промисловості породжує нові та дедалі складніші технологічні процеси, що $є$ джерелом появи специфічних умов експлуатації сенсорів і, відповідно, специфічних вимірювальних задач. Сказане першочергово диктує вимоги як до методів вимірювання, так і до сенсорів, що реалізують ці методи. Здобутки мікроелектронних технологій та матеріалознавства зумовили появу значної кількості типів сенсорів тиску. Однак останніми роками, незважаючи на кількісне зростання номенклатури сенсорів, саме у високотехнологічних галузях різко зросла потреба у сенсорах тиску з принципово новими можливостями i характеристиками. Ця потреба зумовлена необхідністю вимірювання швидкозмінного нестаціонарного тиску в реальному часі, з регламентованим значенням похибки, здебільшого у межах статичної. Зважаючи на це, в цій роботі проаналізовано особливості під час вимірювання нестаціонарного тиску в реальному часі і окреслено необхідні і достатні вимоги до характеристик сенсорів, що дають змогу їх ефективно використовувати. Тому метою роботи є аналіз вимірювання нестаціонарного тиску у реальному часі, скеровано на виявлення особливостей вимірювальної задачі та розроблення способів її розв'язання.
\end{abstract}

Ключові слова: специфіка; вимірювання; нестаціонарний; тиск; реальний час; сенсор. 